\title{
PENINGKATAN HASIL BELAJAR SISWA MENGGUNAKAN MEDIA DAKON MATEMATIKA (DAKOTA)
}

\section{Dwi Cahyadi Wibowo', Ayu Fitri Handayani ${ }^{1}$, Beni Setiawan ${ }^{3}$, Olenggius Jiran Dores ${ }^{4}$. 1,2,3,4 STKIP Persada Khatulistiwa Sintang, Indonesia.}

Email: dwicahyadiwibowo@gmail.com¹, ayufitrihandayaniyani@gmail.com², benisetiawan1892@gmail.com ${ }^{3}$, olenggius@gmail.com ${ }^{4}$

\begin{abstract}
The problem that occurs in Sintang Elementary School in grade IV B is the low value of student learning outcomes in Mathematics material for KPK and FPB. The focus of the problem in this research is the use of math dakon. With the aim to describe the increase in student learning outcomes in mathematics subjects KPK and FPB material using math dakon. Using a qualitative approach form Classroom Action Research conducted in two cycles. Each cycle consists of four stages, namely planning, implementing, observing, and reflecting. The research subjects were students in class IV B of SD Negeri 04 Sintang in the Year Lessons 2019/2020, totaling 23 students. Sources of data came from class IV B students, class IV B teachers, learning activities, and documents. Data collection tools used were observation sheets (teacher and students), test questions, and student and teacher interview sheets. The results showed that (1) by using the math dakon can improve student learning outcomes in Mathematics subject KPK and FPB with very good categories and students play an active role. (2) increasing student learning outcomes using math dakon in the first cycle obtained student learning outcomes by an average of 71.30 and increased in the second cycle to reach 81.73 so that an increase in student learning outcomes by 10.43 the classical completeness level in the first cycle was $65.21 \%$ and the classical completeness level in the second cycle was $91.30 \%$, resulting in an increase in classical completeness by $26.09 \%$. (3) student responses through direct interviews showed positive responses to the mathematical dacons. It can be concluded that the math dakon can improve student learning outcomes in mathematics for the KPK and FPB material class IV B SDN 04 Sintang year lessons $2019 / 2020$.
\end{abstract}

Keywords: Learning Outcomes, Dakota Media

\begin{abstract}
ABSTRAK
Masalah yang terjadi di Sekolah dasar 04 Sintang pada kelas IV B adalah rendahnya nilai hasil belajar siswa pada mata pelajaran Matematika materi KPK dan FPB. Fokus masalah dalam penelitian ini adalah penggunaan media dakon matematika. Dengan tujuan untuk mendeskripsikan peningkatan hasil belajar siswa pada mata pelajaran matematika materi KPK dan FPB dengan menggunakan media dakon matematika. Menggunakan pendekatan kualitatif bentuk Penelitian Tindakan Kelas yang dilaksanakan dalam dua siklus. Tiap siklus terdiri dari empat tahapan, yaitu perencanaan, pelaksanaan, observasi, dan refleksi. Subjek penelitian adalah siswa kelas IV B SD Negeri 04 Sintang Tahun Pelajaran 2019/2020 yang berjumlah 23 orang siswa. Sumber data berasal dari siswa kelas IV B, guru kelas IV B, kegiatan pembelajaran, dan dokumen. Alat pengumpul data yang digunakan yaitu lembar observasi (guru dan siswa), soal tes, dan lembar wawancara siswa dan guru. Hasil penelitian menunjukkan bahwa (1) dengan menggunakan media dakon matematika dapat meningkatkan hasil belajar siswa pada mata pelajaran Matematika materi KPK dan FPB dengan kategori sangat baik dan siswa berperan aktif. (2) peningkatan hasil belajar siswa menggunakan media dakon matematika pada siklus I diperoleh hasil belajar siswa rata-rata sebesar 71,30 dan meningkat pada siklus II mencapai 81,73 sehingga terjadi peningkatan hasil belajar siswa sebesar 10,43 tingkat ketuntasan klasikal pada siklus I sebesar $65,21 \%$ dan tingkat ketuntasan klasikal pada siklus II sebesar $91,30 \%$ sehingga terjadi peningkatan ketuntasan klasikal sebesar 26,09\%. (3) respon siswa melalui wawancara secara langsung menunjukkan respon positif terhadap media dakon matematika. Dapat disimpulkan bahwa media dakon matematika dapat meningkatkan hasil belajar siswa mata pelajaran matematika materi KPK dan FPB kelas IV B SDN 04 Sintang tahun pelajaran 2019/2020.
\end{abstract}

Kata Kunci: Hasil Belajar, Media Dakon Matematika 


\section{PENDAHULUAN}

Pendidikan adalah usaha sadar dan sistematis, yang dilakukan guru yang diserahi tanggung jawab untuk mempengaruhi siswa agar mempunyai sifat dan tabiat sesuai dengan cita-cita pendidikan (Daryanto, 2013: 1). Dalam arti lain, pendidikan merupakan pendewasaan siswa agar dapat mengembangkan bakat, potensi dan keterampilan yang dimiliki dalam menjalani kehidupan, oleh karena itu sudah seharusnya pendidikan didesain guna memberikan pemahaman serta meningkatkan hasil belajar siswa.

Hasil belajar yang optimal juga merupakan salah satu cerminan hasil pendidikan yang berkualitas. Pendidikan yang berkualitas memerlukan sumber daya guru yang mampu dan siap berperan secara profesional dalam lingkungan sekolah dan masyarakat. Lingkungan sekolah meliputi tempat belajar, metode, media, sistem penilaian, serta sarana dan prasarana yang diperlukan untuk menunjang pembelajaran dan kegiatan belajar mengajar sehingga memudahkan siswa belajar. Siswa diharapkan dapat berperan aktif mengikuti proses pembelajaran kemudian dapat melaksanakannya dalam kehidupan nyata siswa.

Matematika sebagai salah satu mata pelajaran yang harus dikuasai oleh siswa pada jenjang SD, SMP, SMA hingga perguruan tinggi. Dalam upaya mengefektifkan pembelajaran matematika, dapat dilakukan mulai dari jenjang yang paling bawah yaitu Sekolah Dasar. Penguasaan matematika di sekolah dasar harus benar-benar mendapat perhatian oleh guru karena akan mempengaruhi proses pembelajaran matematika pada jenjang-jenjang berikutnya. Dimana tujuan utama kurikulum 2013 yaitu menuntut siswa untuk berperan aktif dalam proses pembelajaran serta pembelajaran diimplementasikan sesuai dengan kehidupan nyata siswa. Kurikulum 2013 memungkinkan para guru menilai hasil belajar siswa dalam proses pencapaian sasaran belajar yang mencerminkan penguasaan dan pemahaman terhadap apa yang dipelajari. Oleh karena itu, siswa perlu mempersiapkan dirinya melalui penguasaan terhadap sejumlah kompetensi khususnya pada pembelajaran matematika agar dapat melanjutkan ketingkat penguasaan kompetensi berikutnya dengan hasil belajar yang memuaskan. Hasil belajar yang diharapkan adalah hasil belajar yang mencapai ketuntasan belajar. Siswa dikatakan tuntas apabila nilai hasil belajar siswa mencapai Kriteria Ketuntasan Minimal (KKM) yang ditetapkan.

Berdasarkan data hasil pra observasi di Sekolah Dasar Negeri 04 Sintang, menunjukan bahwa hasil belajar siswa pada mata pelajaran matematika kelas IV B masih kurang. Hal ini dibuktikan dengan rendahnya nilai ulangan harian matematika siswa. Diketahui bahwa KKM untuk pelajaran matematika sebesar 65. Dari KKM tersebut terdapat 10 siswa sekitar $43,48 \%$ yang memenuhi standar KKM, sedangkan 13 siswa sekitar 56,52\% masih belum memenuhi standar tersebut. Sehingga dapat disimpulkan bahwa dari 23 siswa kelas IV B masih banyak yang belum memenuhi kriteria ketuntasan. Selain itu dalam proses pembelajaran di kelas guru menyampaikan materi dengan model pembelajaran langsung, guru menjelaskan materi hanya menggunakan metode ceramah sehingga guru lebih berperan aktif dalam proses pembelajaran sedangkan siswa bersifat pasif dan hanya menerima informasi yang disampaikan oleh guru.

Selain berdasarkan nilai yang diperoleh dari guru, peneliti juga melakukan wawancara terhadap guru yang menunjukan bahwa salah satu faktor penyebab rendahnya hasil belajar siswa pada pembelajaran matematika dikarenakan siswa masih sulit memahami pembelajaran matematika seperti operasi perkalian satu sampai sepuluh. Begitu juga dengan operasi hitung pembagian, meskipun sudah di jelaskan 
oleh guru tetapi siswa belum juga memahaminya. Sedangkan pembelajaran matematika untuk materi operasi perkalian dan pembagian tidak didapatkan lagi di kelas IV. Hal lain dikarenakan guru tidak menggunakan media bantu dalam kegiatan belajar mengajar, khususnya pada pokok pembahasan KPK dan FPB guru hanya mengajarkan dengan cara-cara yang sudah ada sebelumnya.

Selain itu peneliti juga melakukan wawancara terhadap siswa yang nilainya masih rendah. Peneliti memperoleh jawaban antara lain siswa tidak mempelajari lagi di rumah apa yang sudah dijelaskan oleh guru sehingga siswa tidak memahami materi. Kemudian siswa tidak mengerjakan pekerjaan rumah yang diberikan. Tentunya hal tersebut akan berdampak pada nilai pekerjaan rumah siswa. Sedangkan waktu untuk pembelajaran matematika terbatas, 6 jam dalam seminggu 3 jam di hari selasa dan 3 jam lagi di hari kamis. Terkadang siswa tidak mood dan cuek dengan guru sehingga siswa tidak memperhatikan penjelasan guru.

Hal tersebut tentunya akan berdampak terhadap hasil belajar yang diperoleh siswa. Oleh karena itu perlu dilaksanakan pembelajaran yang dapat mengaktifkan dan mengembangkan kegiatan belajar siswa dalam mengemukakan gagasan dan memecahkan masalah-masalah untuk meningkatkan hasil belajar. Salah satu solusi yang dapat diterapkan oleh guru yaitu dengan menggunakan media pada saat mengajar.

Dalam proses pembelajaran khususnya pada mata pelajaran matematika, kehadiran media mempunyai arti yang cukup penting. Karena dalam kegiatan tersebut, ketidakjelasan materi yang disampaikan dapat dibantu dengan menghadirkan media. Kerumitan materi yang akan disampaikan kepada siswa dapat disederhanakan dengan bantuan media.

Media sangat berpengaruh dan berperan penting dalam terciptanya kegiatan belajar mengajar secara baik dan dapat terlaksana dengan efektif, salah satu media yang dapat digunakan untuk proses pembelajaran di kelas adalah media dakon matematika (dakota). Dakon matematika adalah papan yang terdiri dari gelas-gelas bilangan dan menggunakan manik-manik berwarna, dimana satu warna manik mewakili satu bilangan. Menurut Aisyah, dkk (dalam Utami, 2018: 2) permainan dakon bilangan terdiri dari papan dakon, manik-manik warna-warni, serta tutup lubang dakon. Media ini dapat diterapkan pada materi KPK dan FPB. Aspriliana (2018: 2) mengungkapkan bahwa dakon adalah media yang terbuat dari triplek yang dilengkapi dengan 100 buah kantong bilangan yang terbuat dari gelas plastik yang disusun dengan cara 10 x 10 yang telah dilengkapi dengan nomor 1 - 100 dan akan diisi dengan tutup botol aqua. Menurut Istiani dan Arnidha (2018: 68) media dakota memiliki kelebihan antara lain: 1) dapat meningkatkan kreativitas dalam membuat alat ini, selain itu siswa menjadi lebih aktif dan memperoleh pembelajaran yang bermakna dari media "dakota" (FPB dan KPK) ini; 2) dapat melatih siswa dalam berkomunikasi saat berkelompok, menimbulkan motivasi (rasa keingintahuan), menimbulkan keceriaan saat mempraktekkan sebab seperti bermain dakon; 3) sebagai alternatif lain dari penggunaan pohon faktor dan garis bilangan.

Untuk itu, peneliti menerapkan penggunaan media dakon matematika (dakota) pada pembelajaran matematika materi KPK dan FPB untuk membantu dan memudahkan siswa dalam memahami materi pembelajaran sehingga diharapkan dapat meningkatkan hasil belajar yang diperoleh. Aisyah, dkk (dalam Utami, 2018: 2) untuk menyampaikan materi KPK dan FPB dapat menggunakan media dakon matematika (dakota). Dengan menggunakan media dakon matematika (dakota), siswa diharapkan dapat membangun atau menemukan konsep kelipatan, faktor, KPK dan FPB. 
Berdasarkan uraian diatas peneliti bermaksud melakukan penelitian dengan judul : Peningkatkan Hasil Belajar Siswa Menggunakan Media Dakon Matematika (Dakota) Pada Mata Pelajaran Matematika Materi KPK dan FPB Di Kelas IV B SDN 04 Sintang Tahun Pelajaran 2019/2020.

\section{METODE PENELITIAN}

Pendekatan yang digunakan dalam penelitian ini adalah pendekatan kualitatif yang diteliti dengan jenis penelitian tindakan kelas (PTK). Penelitian ini menggunakan metode deskriptif dengan pendekatan kualitatif. Peneliti memilih metode penelitian kualitatif karena dalam penelitian ini peneliti mendeskripsikan keadaan sebenarnya mengenai peningkatan hasil belajar siswa menggunakan media dakon matematika (dakota) pada mata pelajaran matematika materi KPK dan FPB di kelas IV B Sekolah Dasar Negeri 04 Sintang tahun pelajaran 2019/2020. Menurut Kunandar (2016: 44), penelitian tindakan kelas dapat didefinisikan sebagai suatu penelitian tindakan (action research) yang dilakukan oleh guru yang sekaligus sebagai peneliti di kelasnya atau bersama-sama dengan orang lain (kolaborasi) dengan jalan merancang, melaksanakan dan merefleksikan tindakan secara kolaboratif dan partisipatif yang bertujuan untuk memperbaiki atau meningkatkan mutu (kualitas) proses pembelajaran di kelasnya melalui suatu tindakan (treatment) tertentu dalam suatu siklus. PTK adalah penelitian tindakan yang dilakukan dengan tujuan memperbaiki mutu praktik pembelajaran di kelas.

Penelitian ini dilaksanakan di SD Negeri 04 Sintang Jl. Masuka 1 Kelurahan Kapuas Kanan Hilir, Kec. Sintang, Kab. Sintang dengan subyeknya siswa kelas IV B Sekolah Dasar Negeri 04 Sintang tahun pelajaran 2019/2020 dengan jumlah siswanya 23 orang yang terdiri dari 13 laki-laki dan 10 perempuan. Sumber data dalam penelitian terdiri dari sumber data primer dan sumber data sekunder. Teknik pengumpulan data yang dapat digunakan dalam kegiatan penelitian menurut Sugiyono, (2015: 95) antara lain: “1) Teknik observasi langsung, 2) Teknik observasi tidak langsung, 3) Teknik komunikasi langsung, 4) Teknik komunikasi tidak langsung, 5) Teknik pengukuran, 6) Teknik studi dokumenter/bibiografi.'Di antara teknik-teknik pengumpulan data, penelitian ini menggunakan teknik observasi langsung, pengukuran/tes, teknik komunikasi langsung dan dokumentasi. Sedangkan alat pengumpulan data yang digunakan dalam penelitian ini yaitu lembar obsevasi, lembar tes, lembar wawancara, dan dokumen. Dalam penelitian ini peneliti melakukan keabsaan data melalui teknik triangulasi data. Alasan dari penggunaan triangulasi sebagai penentu kevalidan isi karena triangulasi memberi hasil yang tidak menimbulkan keraguan-keraguan informasi dari fenomena yang diseleksi. Teknik analisis data digunakan tahapan yaitu data collection, data reductoin, data display dan conclusion/verification.

\section{HASIL DAN PEMBAHASAN PENELITIAN}

\section{Proses Pembelajaran dengan Menggunakan Media Dakota}

\section{Aktivitas Guru dalam Mengajar}

Aktivitas guru dalam mengajar disesuaikan dengan langkah-langkah Rencana Pelaksanaan Pembelajaran (RPP) yaitu kegiatan pembelajaran menggunakan media dakota, menalar dan mengkomunikasikan, bertanya, mencoba, refleksi, dan penilaian. Hal ini dapat dilihat pada observasi guru. Observasi guru dilakukan untuk menilai aktivitas dan penampilan guru dalam mengajar. Hal ini sejalan dengan pendapat Arifin (2017: 153) mengatakan bahwa observasi dapat digunakan untuk menilai penampilan 
guru dalam mengajar, suasana kelas, hubungan sosial sesama, hubungan sosial sesama siswa, hubungan guru dengan siswa dan perilaku sosial lainnya.

Hasil observasi aktivitas guru selama siklus I adalah sebesar $81 \%$ (hasil observasi guru kelas) dan $81 \%$ (hasil observasi teman sejawat) termasuk dalam kategori baik sekali dan hasil observasi siswa siklus I sebesar 91\% (hasil observasi guru kelas) dan $87,5 \%$ (hasil observasi teman sejawat) Berdasarkan data hasil observasi keterlaksanaan pembelajaran diperoleh rerata aktivitas guru sebesar $81 \%$ dan siswa sebesar $89,25 \%$ pada siklus I termasuk dalam kategori baik sekali, namun belum maksimal sehingga pada siklus II kelemahan-kelemahan yang ditemukan diperbaiki. Kelemahan tersebut disebabkan guru kurang menjelaskan tujuan pembelajaran, memberikan kesempatan kepada siswa untuk bertanya tentang materi yang kurang jelas atau belum dipahami, memberikan evaluasi, dan melakukan refleksi pada siswa dengan tanya jawab tentang materi yang telah diajarkan.

Aktivitas guru akhirnya mengalami peningkatan pada siklus II diperoleh hasil observasi guru mencapai 95\% (observasi guru kelas) dan 95\% (teman sejawat). Hasil observasi aktivitas siswa mencapai 94,5\% (observasi guru kelas) dan 92,5\% (teman sejawat) termasuk dalam kategori baik sekali dengan rerata aktivitas guru sebesar $95 \%$ dan siswa sebesar 93,5\%. Peningkatan terjadi karena guru sudah memperbaiki kelemahan yang terjadi pada siklus I. Jika dilihat dari nilai rata-rata aktivitas guru siklus II maka dapat dikatakan bahwa guru dapat mengelola pembelajaran dengan baik menggunakan media dakota.

Hasil temuan peneliti diperkuat dengan penelitian sebelumnya yang dilakukan oleh Utami (2018) dalam artikel dengan judul "Pengaruh penggunaan media dakon bilangan terhadap hasil belajar peserta didik pada pembelajaran matematika". Hasil penelitian tersebut menyatakan bahwa guru mampu mengelola pembelajaran dengan sangat baik menggunakan media dakon.

\section{Aktivitas Siswa dalam Belajar}

Observasi siswa dilakukan untuk menilai aktivitas siswa saat proses pembelajaran. Hal ini sejalan dengan pendapat Arifin (2017: 153) yang menyatakan bahwa observasi dapat digunakanuntuk menilai proses dan hasil belajar siswa, seperti tingkah laku siswa pada waktu belajar, berdiskusi, mengerjakan tugas dan lain-lain.

Berdasarkan observasi yang telah dilakukan pada siklus I sampai siklus II, kegiatan siswa dalam mengikuti pembelajaran menggunakan media dakota pada materi KPK dan FPB mengalami peningkatan dan dapat dikatakan baik sekali. Hal tersebut terlihat dari pengolahan data pada siklus I diperoleh persentase sebesar $91 \%$ hasil ini diperoleh dari observasi yang dilakukan oleh guru kelas dan 87,5\% hasil observasi yang dilakukan teman sejawat. Selama proses mengajar ada 28 aspek yang diamati pada siswa yang sedang belajar. Pada siklus I ada beberapa aspek yang tidak terlaksana dengan baik yaitu siswa tidak menceritakan pengalaman sehari-hari yang berkaitan dengan materi, siswa tidak bertanya kepada guru tentang materi pembelajaran yang masih kurang jelas atau belum dipahami, siswa tidak menyampaikan pendapat terhadap kegiatan pembelajaran yang dilakukan, dan siswa tidak menarik kesimpulan materi yang dipelajari.

Sedangkan pada siklus II diperoleh sebesar 94,5\% hasil ini diperoleh dari observasi yang dilakukan oleh guru kelas dan 92,5\% hasil observasi yang dilakukan teman sejawat dari 28 aspek yang diamati semua aspek dalam proses belajar terlaksana dengan baik. Aktivitas guru sangat mempengaruhi aktivitas siswa dalam mengikuti pembealajaran. Tugas guru adalah membantu siswa mencapai tujuannya, maksudnya 
guru lebih banyak berurusan dengan strategi daripada memberi informasi.

\section{Peningkatan hasil belajar siswa menggunakan media dakota pada mata pelajaran matematika materi KPK dan FPB di kelas IV B Sekolah Dasar Negeri 04 Sintang tahun pelajaran 2019/2020.}

Hasil belajar siswa dapat dilihat dari hasil tes yang telah diberikan kepada siswa ketika diakhir proses pembelajaran pada siklus I dan siklus II. Indikator hasil belajar yang digunakan dalam penelitian ini yaitu 1) mengingat (C1);2) memahami (C2); menerapkan (C3); dan menganalisis (C4). Perolehan hasil belajar materi KPK dan FPB pada siklus I menunjukkan hasil yang sudah cukup baik. Pada indikator hasil belajar yang pertama yaitu megingat $(\mathrm{C} 1)$. Menurut Bloom dalam Sudjana (2016: 50) mengatakan bahwa pengetahuan itu perlu dihafalkan, diingat agar dapat dikuasai dengan baik. Ada beberapa cara untuk dapat mengingat/menguasai, misalnya dibaca berulang-ulang dan menggunakan teknik mengingat. Indikator pertama (C1) siklus I pada soal nomor 1 dan 4 yaitu siswa dapat menyebutkan faktor dan kelipatan dari suatu bilangan. Dari soal nomor 1 dan 4 diperoleh jumlah perindikator 85,5 dengan rata-rata 3,717391955. Indikator kedua (C2) siklus I pada soal tes nomor 2, 3 dan 5 yaitu siswa dapat memahami faktor persekutuan dan kelipatan persekutuan dari dua bilangan. Untuk soal nomor 2, 3, dan 5 didapatkan jumlah perindikator 77,3 dengan rata-rata 3,36231942. Indikator ketiga (C3) siklus I pada soal tes nomor 6, 7, 8 yaitu siswa dapat menentukan kelipatan persekutuan, KPK, faktor persekutuan dan FPB dari dua bilangan. Untuk soal nomor 6, 7, dan 8 didapatkan jumlah perindikator 62,3 dengan rata-rata 2,7101433333. Dan indikator keempat (C4) siklus I pada soal tes nomor 9 dan 10 yaitu siswa mampu menyelesaikan soal cerita KPK dan FPB dari dua bilangan. Untuk soal nomor 9 dan 10 didapatkan jumlah perindikator 37 dengan ratarata 1,608695. Indikator pertama (C1) siklus II pada soal nomor 1, 2 dan 5 yaitu siswa dapat menyebutkan faktor dan kelipatan dari suatu bilangan. Dari soal nomor 1, 2 dan 5 diperoleh jumlah perindikator 82,3 dengan rata-rata 3,57971. Indikator kedua (C2) siklus II pada soal tes nomor 3, 4 dan 6 yaitu siswa dapat memahami faktor persekutuan dan kelipatan persekutuan dari dua bilangan. Untuk soal nomor 3, 4 dan 6 didapatkan jumlah perindikator 73,3 dengan rata-rata 3,1884066667. Indikator ketiga (C3) siklus II pada soal tes nomor 7, 8, 9 yaitu siswa dapat menentukan kelipatan persekutuan, KPK, faktor persekutuan dan FPB dari dua bilangan. Untuk soal nomor 7, 8 dan 9 didapatkan jumlah perindikator 69,3 dengan rata-rata 3,0144933333. Dan indikator keempat (C4) siklus II pada soal tes nomor 10 yaitu siswa mampu menyelesaikan soal cerita KPK dan FPB dari dua bilangan. Untuk soal nomor 10 didapatkan jumlah perindikator 60 dengan rata-rata 2,6087. Penggunaan media dakota merupakan media yang membantu guru untuk menyampaikan materi kepada siswa agar siswa lebih mudah memahami materi serta makna dari penggunaan media dakota yang digunakan. Hasil belajar siswa materi KPK dan FPB secara umum menunjukkan bahwa terjadi peningkatan dari siklus I ke siklus II. Berdasarkan hasil tes yang diperoleh, diketahui pada siklus I nilai rata-rata siswa sebesar 71,30 dengan jumlah siswa yang dinyatakan tuntas sebanyak 15 siswa, dengan persentase 65,21\%. Sedangkan siswa yang tidak tuntas berjumlah 8 siswadengan persentase $34,79 \%$.

Kemudian pada siklus II, diketahui nilai rata-rata siswa sebesar 81,73 dengan jumlah siswa yang dinyatakan tuntas berjumlah 21 siswa, dengan persentase $91,30 \%$. Sedangkan siswa yang tidak tuntas berjumlah 2 siswa, dengan persentase $8,7 \%$. Penelitian ini sudah mencapai target maksimal dan dinyatakan berhasil karena peningkatan jumlah siswa yang tuntas (masuk dalam kategori mencapai target sesuai 
(KKM) sudah mencapai 85\% dengan peningkatan sebesar 26,09\% .

Peningkatan rata-rata hasil belajar siswa materi KPK dan FPB tentunya tidak terlepas dengan adanya penggunaan media dakota serta LKS yang dirancang berdasarkan menggunakan media dakota dalam proses pembelajaran. Pada siklus I ditemukan bahwa siswa belum terampil dalam menggunakan media dakota. Kemudian pada saat mengerjakan LKS siswa belum memahami secara maksimal cara pengerjaan LKS, siswa mengerjakan LKS tanpa berdiskusi, dan siswa malu bertanya mengenai masalah yang dihadapi mengerjakan LKS. Pada siklus II siswa sudah memahami pengerjaan LKS, dan siswa mengerjakan LKS dengan berdiskusi bersama kelompoknya. Selain itu, siswa sudah berani untuk bertanya dan menyampaikan pendapatnya pada saat mempresentasikan hasil diskusi.

Hasil ini sejalan dengan hasil penelitian yang dilakukan oleh Fauziddin (2016) dalam judul penelitian "Peningkatan hasil belajar matematika melalui model pencapaian konsep dengan bantuan alat peraga dakon bilangan pada materi KPK dan FPB kelas IV SDN 001 Petapahan Kecamatan Tapung" berdasarkan hasil penelitian dan pembahasan, diperoleh bahwa ketercapaian KKM sebelum tindakan sebanyak 15 siswa dari 25 siswa (60\%) sedangkan setelah tindakan pada siklus I sebanyak 18 siswa dari 25 siswa (72\%) dan pada siklus II sebanyak 22 siswa dari 25 siswa (88\%).

Berdasarkan hasil penelitian tersebut dapat disimpulkan bahwa penggunan media dakota dapat meningkatkan hasil belajar siswa pada mata pelajaran matematika materi KPK dan FPB. Oleh karena itu, penelitian ini dapat dijadikan suatu pertimbangan bagi guru yang ingin menggunakan media dakota yang dapat meningkatkan hasil belajar siswa. Dengan demikian penggunaan media dakota di kelas IV B SD Negeri 04 Sintang tahun pelajaran 2019/2020 dapat meningkatkan hasil belajar siswa materi KPK dan FPB.

\section{Respon Siswa terhadap Penggunaan Media Dakota pada Materi KPK dan FPB di Kelas IV B SDN 04 Sintang Tahun Pelajaran 2019/2020.}

Berdasarkan hasil wawancara terhadap penggunaan media dakota terlihat respon siswa terhadap penggunaan media dakota sangat baik. Wawancara telah dilakukan kepada 15 orang siswa, lima siswa dengan berkemampuan tinggi, lima siswa dengan berkemampuan sedang, dan lima siswa dengan berkemampuan rendah. Respon siswa terhadap penggunaan penggunaan media dakota dalam meningkatkan hasil belajar siswa terbukti pada saat proses pembelajaran berlangsung siswa sangat senang, tertarik, tidak bosan untuk mengikuti pembelajaran dari awal sampai akhir pembelajaran. Siswa dapat menggunakan media dakota dengan baik sesuai diharapkan serta hasil belajar juga sesuai dengan yang diharapkan peneliti, dengan hasil tersebut maka penelitian ini berhenti sampai dengan siklus II dan tidak dilakukan lagi tindakan ke siklus berikutnya.

Dari hasil wawancara didapatkan kesimpulan bahwa respon siswa pada materi yang diajarkan dapat dimengerti dan dipahami oleh siswa dengan berbantu media dakota, siswa tidak mengalami kesulitan dan tidak bosan selama mengikuti pembelajaran karena siswa tertarik menggunakan media yang memiliki banyak warna. Hasil wawancara siswa secara keseluruhan dikatakan bahwa siswa memberikan respon yang positif dan tanggapan sangat baik terhadap penggunaan media dakota.

\section{PENUTUP}

Berdasarkan rumusan masalah, hasil pengolahan dan analisis data serta pembahasan dapat disimpulkan secara umum bahwa peningkatan hasil belajar siswa 
menggunakan media dakon matematika (dakota) pada mata pelajaran matematika materi KPK dan FPB di kelas IV B SDN 04 Sintang tahun pelajaran 2019/2020 mengalami peningkatan. Kesimpulan didasarkan pada hasil siklus I dan siklus II yang dijabarkan sesuai dengan rumusan masalah yang diteliti yaitu: (1) Proses pembelajaran menggunaan media dakon matematika (dakota) pada mata pelajaran matematika materi KPK dan FPB di kelas IV B Sekolah Dasar Negeri 04 Sintang tahun pelajaran 2019/2020 dikategorikan baik sekali hasil observasi aktivitas belajar siswa pada siklus I diperoleh rerata sebesar $89,25 \%$ dengan kriteria baik sekali, pada siklus II hasil aktivitas siswa diperoleh rerata sebesar 93,5\% dengan kriteria baik sekali. (2) Peningkatan hasil belajar siswa menggunakan media dakon matematika (dakota) pada mata pelajaran matematika materi KPK dan FPB di kelas IV B Sekolah Dasar Negeri 04 Sintang tahun pelajaran 2019/2020 diperoleh hasil belajar siswa pada siklus I dengan nilai tertinggi 100 dan nilai terendah 27,5 terjadi peningkatan pada siklus II dengan nilai tertinggi 97,5 dan nilai terendah 50 nilai rata-rata kelas 71,30 dengan ketuntasan klasikal dalam belajar $65,21 \%$, siklus II rata-rata kelas meningkat menjadi 81,73 dengan ketuntasan klasikal dalam belajar 91,30\% dari hasil siklus nilai rata-rata meningkat sebesar 10,43 dan ketuntasan klasikal meningkat sebesar 26,09\%. (3) Respon siswa setelah menggunakan media dakon matematika (dakota) pada mata pelajaran matematika materi KPK dan FPB di kelas IV B Sekolah Dasar Negeri 04 Sintang tahun pelajaran 2019/2020 menunjukkan respon yang sangat baik, hal tersebut terbukti dari sikap siswa yang merasa senang, tertarik dan ingin mencoba dalam pembelajaran dengan menggunakan media dakota siswa tidak merasa bosan, tertarik, dan dapat memperhatikan penjelasan dengan baik dalam mengikuti proses pembelajaran dari awal sampai dengan akhir pembelajaran, berdasarkan uraian tersebut dapat dikatakan bahwa respon siswa terhadap penggunaan media dakota dalam meningkatkan hasil belajar siswa sangat positif.

Berdasarkan hasil penelitian mengenai peningkatan hasil belajar siswa menggunakan media dakota pada mata pelajaran matematika materi KPK dan FPB di kelas IV B SDN 04 Sintang tahun pelajaran 2019/2020, maka saran yang diberikan sebagai sumbangan pemikiran dan perencanaan untuk meningkatkan mutu pendidikan dan untuk meningkatkan hasil belajar siswa kelas IV B SDN 04 Sintang sebagai berikut: (1) Siswa hendaknya ikut berperan aktif dalam pembelajaran dengan memberikan pendapat tentang materi pembelajaran yang dipelajari dan cara penyampaian materi oleh guru yang bisa siswa pahami agar apa yang guru sampaikan dapat diterima dengan baik oleh siswa serta siswa hendaknya membiasakan diri dengan sering-sering mengajukan pertanyaan dan menyampaikan pendapat atau saling bertukar pendapat antar teman. (2) Dalam menjelaskan materi pembelajaran guru sebaiknya jangan terlalu sering menggunakan metode ceramah, tetapi akan lebih efektif jika guru menggunakan media-media pembelajaran yang simple tetapi menarik serta guru dapat memanfaatkan barang-barang yang jarang digunakan dengan membuat sebuah media yang menarik tapi simple dalam membantu guru menjelaskan materi agar lebih mudah dipahami oleh siswa dan guru dapat berinteraksi, lebih mendekatkan diri pada siswa, dan berusaha mengenal karakter siswa, agar siswa tidak merasa takut ataupun siswa lebih merasa diperhatikan oleh guru. (3) Hasil penelitian ini diharapkan dapat dijadikan acuan bagi guru dan sebagai salah satu upaya dalam memberikan masukan kepada guru mengenai pelaksanaan pembelajaran menggunakan media dakota dalam upaya meningkatkan hasil belajar siswa. (4) Perlu adanya kajian yang jauh mengenai penggunaan media dakotaguna untuk meningkatkan hasil belajar siswa pada mata pelajaran Matematika materi KPK dan FPB, serta hasil penelitian ini 
diharapkan dapat menjadi referensi dalam pengembangan sistem pelayanan bagi peneliti selanjutnya yang tertarik untuk meneliti tentang hasil belajar siswa menggunakan media dakota dan sebagai salah satu acuan sakaligus perbandingan untuk kegiatan penelitian.

\section{DAFTAR PUSTAKA}

Andri. dan Rismawati. M. 2018. "Analisis Faktor-Faktor yang Mempengaruhi Rendahnya Hasil Belajar Konsep Dasar Matematika SD pada Mahasiswa PGSD". Jurnal VOX Education. Volume 9 No. 2 Hal 91-101.

Arifin, Z. 2017. Evaluasi Pembelajaran. Bandung: Remaja Rosdakarya Offset.

Arikunto, S. 2015. Dasar-Dasar Evaluasi Pendidikan. Jakarta: Bumi Aksara.

Aspriliana, R. 2018. "Pengaruh Media Dakon Bilangan Terhadap Hasil Belajar FPB dan KPK Siswa SDN 34 Pontianak". Artikel. Pontianak: Fakultas Keguruan dan Ilmu Pendidikan Universitas Tanjungpura.

Aunurrahman. 2014. Belajar dan Pembelajaran. Bandung: Alfabeta.

Daryanto. 2013. Media Pembelajaran (Peranannya Sangat Penting Dalam Mencapai Tujuan Pembelajaran). Yogyakarta: Gava Media.

Fauziddin, M. 2016. "Peningkatan Hasil Belajar Matematika Melalui model Pencapaian Konsep dengan Bantuan Alat peraga Dakon Bilangan Pada Materi KPK dan FPB Di Kelas IV SDN 001 Petapahan Kecamatan Tapung”. Artikel. Petapahan: STKIP Pahlawan Tuanku Tambusai".

Istiani. A. dan Arnidha. Y. 2018. "Pendampingan Pembuatan dan Penggunaan Alat Peraga Dakota pada Pembelajaran FPB dan KPK". Jurnal Publikasi Pendidikan. Volume 8 No. 1 Hal 66-70.

Kanginan, M. dan Darmawan, A. B. 2017. Matematika Untuk Siswa SD/MI Kelas IV. Bandung: Sarana Tutorial Nurani Sejahtera.

Kunandar. 2016. Langkah Mudah Penelitian Tindakan Kelas Sebagai Pengembangan Profesi Guru. Jakarta: RajaGrafindo Persada.

Majid, A. 2014. Penilaian Autentik Proses Dan Hasil Belajar. Bandung: Remaja Rosdakarya Offset.

Moleong, L. J. 2014. Metodologi Penelitian Kualitatif. Bandung: Remaja Rosdakarya Offset.

Musfiqon. 2012. Pengembangan Media \& Sumber Pembelajaran. Jakarta: Prestasi Pustakaraya.

Renita. 2017. "Keefektifan Media Dakon Modifikasi Terhadap Peningkatan Hasil Belajar Matematika pada Siswa Tunanetra Kelas V Di SD Luar Biasa A Yaketunis". Skripsi. Yogyakarta: Universitas Negeri Yogyakarta.

Sudjana, N. 2016. Penilaian Hasil Proses Belajar Mengajar. Bandung: Remaja Rosdakarya Offset.

Sugiyono. 2013. Metode Penelitian Pendidikan (Pendekatan Kuantitatif, Kualitatif dan $R \& D)$. Bandung: Alfabeta.

2017. Metode Penelitian Kuantitatif, Kualitatif dan $R \& D$. Bandung: Alfabeta.

Susanto, A. 2016. Teori Belajar \& Pembelajaran di Sekolah Dasar. Jakarta: Prenadamedia Group.

Utami, D. W. 2018. "Pengaruh Penggunaan Media Dakon Bilangan Terhadap Hasil Belajar Peserta Didik pada Pembelajaran Matematika". Artikel. Pontianak: Fakultas Keguruan dan Ilmu Pendidikan Universitas Tanjungpura.

Yunista, 2018. "Penerapan Pembelajaran Contextual Teaching And Learning (CTL) 
untuk Meningkatkan Pemahaman Konsep Operasi Hitung Perkalian dan Pembagian pada Peserta Didik Kelas III C SD Negeri 20 Mambok Tahun Pelajaran 2018/2019”. Skripsi. Sintang: STKIP Persada Khatulistiwa. 